\title{
Pulmonary Hyalinizing Granuloma: A Case Report
}

\author{
Elias Amorim¹, Raimunda Ribeiro da Silva², Armando da Veiga Cruz Filho ${ }^{2}$ \\ ${ }^{1}$ Presidente Dutra Hospital of the Federal University of Maranhão, São Luiz, Brazil \\ ${ }^{2}$ University Hospital of the Federal University of Maranhão, São Luiz, Brazil \\ Email: amorimelm@gmail.com
}

How to cite this paper: Amorim, E., da Silva, R.R. and da Veiga Cruz Filho, A. (2016) Pulmonary Hyalinizing Granuloma: A Case Report. Open Journal of Thoracic Surgery, 6, 70-73.

http://dx.doi.org/10.4236/ojts.2016.64009

Received: October 26, 2016

Accepted: December 12, 2016

Published: December 15, 2016

Copyright $\odot 2016$ by authors and Scientific Research Publishing Inc. This work is licensed under the Creative Commons Attribution International License (CC BY 4.0).

http://creativecommons.org/licenses/by/4.0/

\begin{abstract}
Pulmonary hyalinizing granuloma (PHG) is a rare nodular disease of unknown etiology. PHG can present with solitary or bilateral lung nodules and be asymptomatic or present with fever, cough, dyspnea, chest pain and hemoptysis.
\end{abstract}

\section{Keywords}

Hyalinizing, Granuloma, Pulmonary, Nodular

\section{Introduction}

Pulmonary hyalinizing granuloma ( $\mathrm{PHG}$ ) is a rare benign disease of unknown etiology characterized pathologically by deposits of lamellar collagen [1].

PHG was first described in 1977 by Englemann et al. [2].

Clinically, PHG can be asymptomatic (25\% of all patients) or present with dry cough, fever, dyspnea and hemoptysis [3].

The disease can exhibit slow growth and progressive enlargement or concomitant multiple nodules that can mimic metastatic disease [4].

PHG can be associated with autoimmune diseases or previous lung infections.

Definitive diagnosis is confirmed by histopathological study of the lesion [5].

Radiological and tomographic findings disclose randomly distributed nodules with well-defined borders many of which may exhibit calcification. Although calcification is often not evident, it is generally focal, central and irregular [6].

Few complications have been associated with PHG and patients usually have an excellent prognosis.

Because symptoms are mild, many lesions are incidental radiological findings and not correctly diagnosed initially [7]. 
Final conclusive diagnosis is based on histopathological analysis of the nodule biopsy specimen [8].

\section{Case Report}

A 70-year-old patient in excellent general health was referred from another hospital with infrequent cough and no complaints of chest pain. Results of physical exam and blood work-up were unremarkable.

The patient had no history of tuberculosis or any other lung diseases such as pneumonia. The patient reported no hemoptysis or lung infection.

Chest radiographs disclosed different sized regular nodules bilaterally, confirmed by computed tomography. Some lesions were calcified. Bronchoscopy findings were normal.

Metastatic disease was suggested and primary lesion diagnosed.

Positron emission tomography (PET-CT) was performed and demonstrated no further lesions at other sites.

Lung needle biopsy was initially proposed but owing to the presence of peripheral lesion (Figure 1), (Figure 2) video-assisted biopsy was carried out.

\section{Discussion}

Pulmonary hyalinizing granuloma can present with multiple nodules and importantly, is included in the differential diagnosis of more common diseases such as tuberculosis, histoplasmosis and aspergillosis. Other differential diagnoses include inflammatory pseudotumor and solitary inflammatory tumor of the pleura [3].

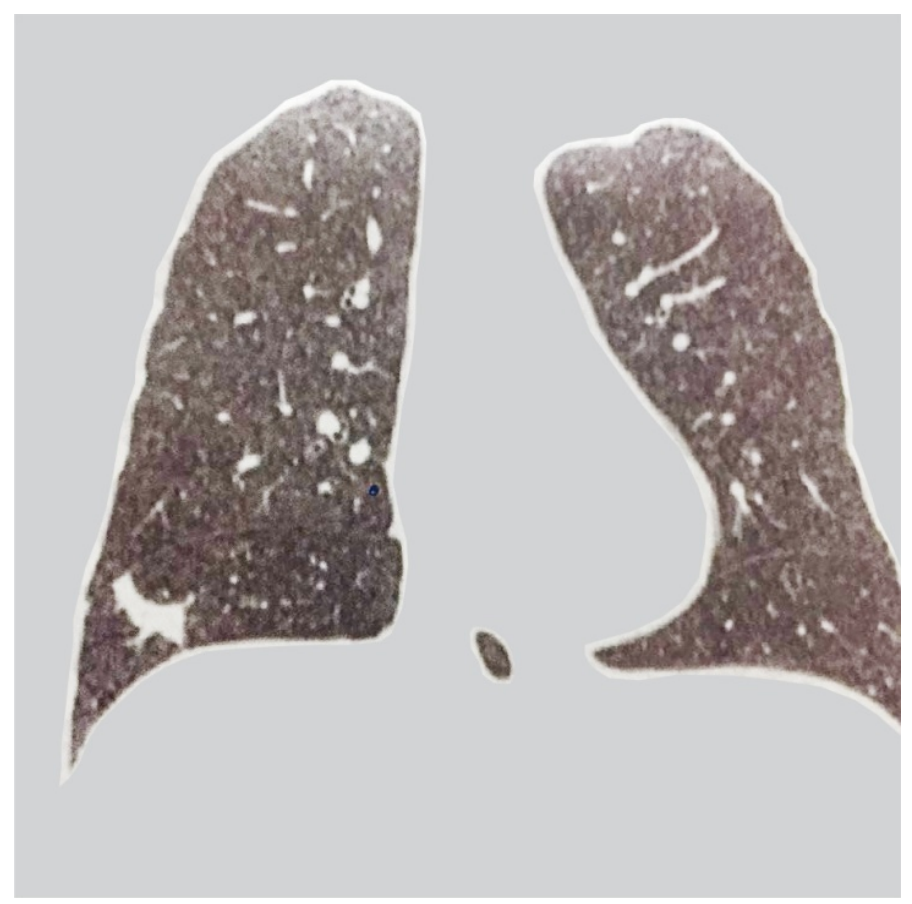

Figure 1. Tomography presenting lung parenchyma with lump. 


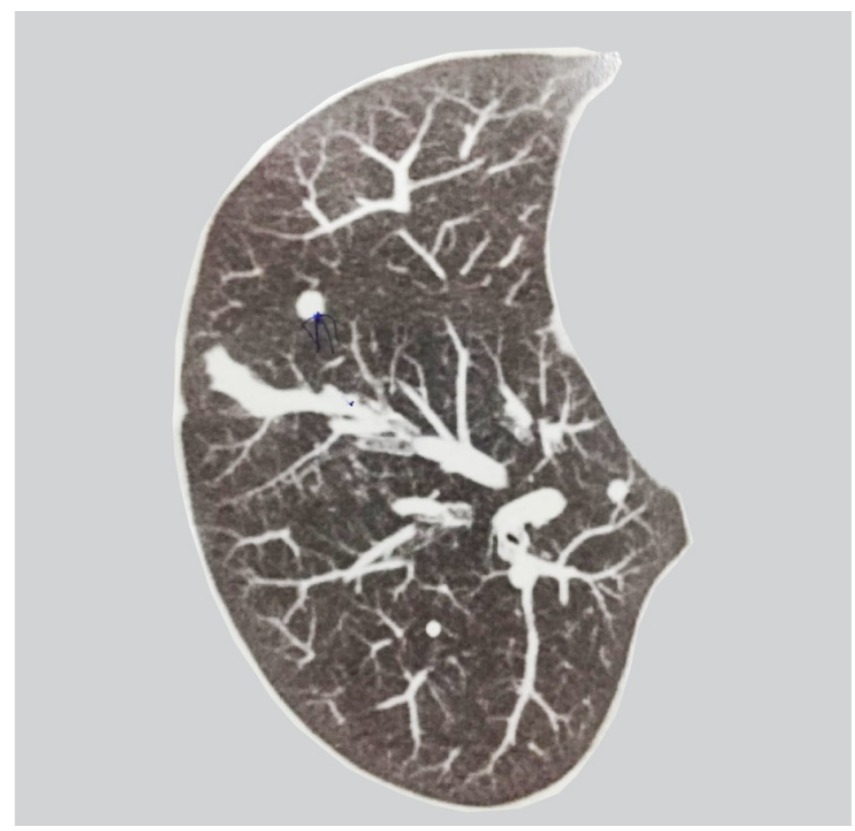

Figure 2. Tomography presenting multiple nodules.

Differentiation of malignancy and final diagnosis normally require surgical biopsy, as performed in the present case, where the patient underwent video-assisted thoracoscopic surgery employed in cases of solitary or bilateral nodules.

PHG is a benign, sometimes recurrent condition, with no predilection for gender that is predominantly multinodular, as in the case reported. The disease can be asymptomatic in up to $25 \%$ of cases [9] and typically affects adults aged 19 - 77 years, predominantly in the fifth decade of life. The patient reported was 70 years old. Although prognosis is generally good, given largely benign progression it can result in respiratory failure due to lesion growth and fibrosis [10].

\section{Conclusions}

Pulmonary hyalinizing granuloma is a rare disease generally involving a benign lesion, especially in asymptomatic patients.

Patients should be assessed for other diseases to confirm presence confined to the lung only, particularly when nodules are disseminated in both lungs.

\section{References}

[1] Goot, V., Harri, C., Maulenaer, A., Watson, B. and Safford, S.D. (2015) A Rare Case of Pulmonary Hyalinizing Granuloma with Calcificationa 5 Year Old Boy. Journal of Pediatric Surgery Case Reports, 3, 123-126. https://doi.org/10.1016/j.epsc.2015.01.001

[2] Engleman, P., Liebow, A.A., Gmelich, J. and Friedman, P.J. (1977) Pulmonary Hyalinizing Granuloma. American Review of Respiratory Disease, 115, 997-1008.

[3] Arruda, G.D.S., Carvalho, P.C.R., Andrade, M.P.G., Cusmanich, M.C., Bandeira, G. and Tozaki, F.S.P. (2010) Recurente Pulmonary Hyalinizing Granuloma. Jornal Brasileiro de Pneumologia, 36, 1-4. https://doi.org/10.1590/S1806-37132010000500019 
[4] Coleman, C., Aziza, N. and McComb, B. (2014) Pulmonary Hyalinizing Granuloma Associeted with Idiopatic Thrombocytopenic Purpura. Journal of Clinical Imaging Science, 4, 1-4. https://doi.org/10.4103/2156-7514.127835

[5] Boutayeb, L., Genéhilós, M. and Mayayo, E. (2012) Pulmonary Hyalinizing Granuloma. Archivos de Bronconeumología, 48, 344-345. https://doi.org/10.1016/j.arbres.2012.03.005

[6] Rahatullah, A., Waheed, Z., Khan, J.A. and Din, N.U. (2012) Pulmonary Hyalinizing Granuloma: A Rare Pulmonary Disorder. Journal of the Pakistan Medical Association, 62, 495-495. http://ecommons.aku.edu/pakistan_fhs_mc_med_pulm_critcare/3

[7] Brandão, V., Machiori, E., Zaneti, G., Abdalla, G., Ventura, N., Constantino, C.L., et al. (2010) Hyalinizing Granuloma: An Unusual Case of a Pulmonary Mass. Case Reports in Medicine, 2010, Article ID: 984765. https://doi.org/10.1155/2010/984765

[8] Düzgün, N., Kurtipek, E., Esme, H., Karanis, M.I.E. and Tolu, I. (2015) Pulmonary Hyalinizing Granuloma Mimicking Metastatic Lung Cancer. Case Reports in Pulmonology, 2015, Article ID: 610417. https://doi.org/10.1155/2015/610417

[9] Ramirez, J., Mehta, J.B., Taylor, R.A., Byrd Jr., R.P. and Roy, T.M. (1998) Symptomatic Pulmonary Hyalinizing Granuloma. Southern Medical Journal, 91, 867-869. https://doi.org/10.1097/00007611-199809000-00014

[10] Marchiori, E., Valiante, P.M., Correa, A.H.P., Carneiro, L.H., Caldas, C.R. and Souza, A.S. (2003) Granulomas Hialinizantes Pulmonares: Aspectos na tomografia computadorizadaRelato de Caso. Radiologia Brasileira, 36, 1-6. https://doi.org/10.1590/s0100-39842003000600011

\section{Submit or recommend next manuscript to SCIRP and we will provide best service} for you:

Accepting pre-submission inquiries through Email, Facebook, LinkedIn, Twitter, etc. A wide selection of journals (inclusive of 9 subjects, more than 200 journals)

Providing 24-hour high-quality service

User-friendly online submission system

Fair and swift peer-review system

Efficient typesetting and proofreading procedure

Display of the result of downloads and visits, as well as the number of cited articles

Maximum dissemination of your research work

Submit your manuscript at: http://papersubmission.scirp.org/

Or contact ojts@scirp.org 